\title{
An Index that Correlates Service Performance and Energy Consumption of Belt Conveyors
}

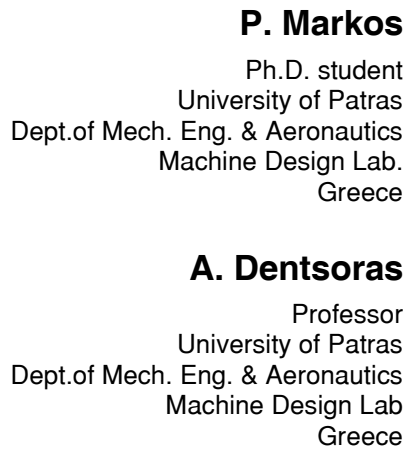

P. Markos Machine Design Lab.

Greece

ras

Greece

In the present paper, an index is proposed for belt conveyors that represents the evaluation of the overall functional/design efficiency by considering both energy and service performance. To obtain index value, energy consumption data - that are extracted from a detailed energy analysis of the examined conveyor - are correlated to service performance data derived from the analysis of material handling capability of the conveyor within the context of the set operational requirements and functional conditions. The proposed index is exemplified through a case study of a simple inclined belt conveyor for which a detailed energy consumption model is developed. Different technical specifications and operational conditions are tested. The proposed approach proves that the index depicts adequately the effect of any design solution or operational decision to the overall efficiency of the conveyor.

Keywords: Index, Service performace, Energy consumption, Belt conveyor

\section{INTRODUCTION}

Belt conveyors are extensively applied in material handling and their operation is frequently characterized by high operational intensity and handling capacity and very long operational times. As conveying systems, they play a major role in handling bulk and unit loads along horizontal or inclined paths of different lengths in both out- and indoor applications and in different applications in the industrial production flow lines. They are used as principal components in some complex machines such as wheel excavators, conveyor bridges etc. For all these reasons, belt conveyors consume significant amounts of energy and, consequently, the increase of their energy efficiency is a matter of major importance in both cost and environmental terms.

Within the context of the recent research in the fields mentioned above, Clenet proposes the use of appropriate electronic devices and control strategies for the energy consumption reduction of belt conveyors [1]; Gunthner, Tilke and Rakitsch examine the potentials in energy savings in operation of belt conveyors and other conveying machines [6], He, Pang and Lodewijks examine the energy savings in long belt conveyors after the application of speed control [8]; Zhang and Xia propose a model for the improvement of energy efficiency at the operational level [15]; Wheeler provides a theoretical method to calculate resistances of rotating components [14]; Luo, Huang and Zhang aim at energy cost optimal operation of coal handling belt conveyors in coal-fired power plant via the use of control for forecasting coal consumption and feeding

Received: January 2018, Accepted: March 2018

Correspondence to: Argyris Dentsoras, Professor

Machine Design Lab., Dept.of Mech. Eng. \&

Aeronautics University of Patras, 26500, Patras, Greece,

E-mail: dentsora@mech.upatras.gr

doi:10.5937/fmet1803313M,

(C) Faculty of Mechanical Engineering, Belgrade. All rights reserved rate to conveyors [9] and Mathaba and Xia propose a parametric energy model for belt conveyors with long troughed belts, that incorporates a partial differential equation to capture the variable amount of material mass per belt unit length [12].

It seems that most of the research work focuses on the optimization of energy consumption at the design and/or at the operational level. However, a point of major importance for the design and operation of conveying machines is their conveying capability per se. The installation and operation of "fast" conveyors with high conveying capabilities can increase substantially the overall efficiency of production flows in terms of time exploitation and production cost. On the contrary, the limited handling capacity of conveyors may convert them in production flow "bottlenecks" that affect the rest processes of the flow line. It is therefore necessary to design and operate conveyors which are energy efficient while, at the same, present high transportation capability.

In this context, in the present paper the design and the operation of a belt conveyor is examined by taking into account the combination of energy efficiency, conveying capability and service performance. Thus, a index is proposed that correlates data obtained by the energy analysis and data derived from the service performance analysis of the examined belt conveyor. The index value corresponds to a certain set of design specifications and operational conditions (energy and service performance). In the context of service performance, the amount of transported material, the covered distance and the velocity of transportation are considered.

The proposed index is inteded to be of generic value and it is planned to be used in the future also for other conveyor types. It has been inspired by past works of Markos and Dentsoras $[10,11]$ where early expressions of similar indexes had been proposed for elevators and 
escalators. Another close work is that of Hagert and Hintz [7] who proposed a norm for the energy efficiency of long belt conveyors, however this norm considers the energy consumed in relation only to the amount of transported material load and the covered distance, but not in relation to conveying speed, so it lacks of crucial information for the complete evaluation of service performance.

For the exemplification of the proposed index, an single-drive, inclined belt conveyor is examined for its conveying capability and its energy consumption via a simple model with sufficient detail level.

\section{PRESENTATION OF THE INDEX OF SERVICE - ENERGY PERFORMANCE FOR CONVEYORS}

The proposed index for the evaluation of the overall efficiency of a conveying machine by correlating both energy and service performance is called Index of Service-Energy Performance (abbr. ISEP) and is determined by the following expression:

$$
I S E P_{T}=\frac{\sum_{1}^{n}\left[M_{T P} \cdot\left(\frac{E_{T P} \cdot t_{t r / T P}}{M_{T P} \cdot L_{t r}}\right)\right]}{\sum_{1}^{n} M_{T P}}(\mathrm{~J} \cdot \mathrm{s} / \mathrm{kg} \cdot \mathrm{m})
$$

where index $(T)$ refers to a certain reference period (e.g. day, month or year). This period may be further divided in $n$ time sub-periods with subscript $(T P)$ that may have different duration $\left(t_{T P}\right)$ and/or different conveying loads. In every sub-period $(T P)$ the total consumed energy $\left(E_{T P}\right)(\mathrm{J})$ is multiplied by the average transportation time $\left(t_{t r / T P}\right)(\mathrm{s})$ of a unit mass of the conveyed material and then is divided by the total material mass $\left(M_{T P}\right)(\mathrm{kg})$ that has been transported during $(T P)$ and the total length of transportation $\left(L_{t r}\right)(\mathrm{m})$. For every sub-period $(T P)$, the ratio $E_{T P} \cdot t_{t r / T P} / M_{T P} \cdot L_{t r}$ represents the amount of energy consumed by the conveyor to transport a certain material load in relation to the path to be covered and the time duration of the conveying. (ISEP) is calculated for a longer period $(T)$, where the various sub-periods $(T P)$ correspond proportionately to the time needed for conveying material mass $\left(M_{T P}\right)$. (ISEP) contains both the energy consumption and the transportation service "quantity" and "speed". It should be underlined that lower values of (ISEP) correspond to higher values of overall conveyor efficiency and vice versa.

The value of (ISEP) is sensitive to decisions made during both design and operation periods because it depends upon $\left(E_{T P}\right),\left(t_{t r / T P}\right)$ and $\left(L_{t r}\right)$, parameters that are strongly dependent to structural/functional elements and operational conditions. The index can also depict the efficiency of maintenance if values of the parameters that are included in expression (1) are derived from measurements on the field. Moreover, (ISEP) can be used as an evaluation tool for various technical changes on a conveyor in cases where its modernization is scheduled or when conveying parameters of the facility where it is installed have changed significantly and the stakeholders wish to maintain conveyor's overall efficiency.
Considering the transportation path in (ISEP) as it is expressed by parameter $\left(L_{t r}\right)$, there are two distinctive ways to apply the proposed index. The first way is to apply (ISEP) with respect to the specific conveyor topology which is usually imposed by multiple external operational factors. Given the topology, various technical specifications of the conveyor and different operational strategies can be evaluated for their overall efficiency in terms of transportation service and energy consumption. The second way is when only the start and end points are considered, and engineers are free to choose from a variety of conveyor topologies. In this seldom case, $\left(L_{t r}\right)$ represents the straight line between that two points and, rationally, the most efficient conveyor topology should be the one that converges to that line as close as possible.

\section{A CASE STUDY OF A BELT CONVEYOR FOR THE EXEMPLIFICATION OF INDEX OF SERVICE - ENERGY PERFORMANCE}

The total energy consumed by a conveyor is the sum of the partial energies consumed: a. for the transportation of the requested load, b. for overcoming all types of motion/inclination resistances, c. for the acceleration of load and conveyor masses (it is assumed that there is load on the belt when conveyor starts and d. for the auxiliary functions of the electrical sub-systems. The available technical literature provides with extensive data for performing analytical calculation for the majority of these different "energies" for a wide spectrum of conveyor types. Without making references to secondary details that would not not comply to the purpose of the present paper, emphasis is given to the exemplification of (ISEP).

A case study of a certain belt conveyor is developed below (see figure 1 above). To emphasize on (ISEP), all parts are supposed to have been designed correctly considering their strength for stresses. It is also assumed that any possible elongation of the belt during conveyor acceleration in each start and during steady state operation under heavy loading is negligible and that the acceleration in each start will not cause any problems to conveyor subsystems. The energy consumption model maintains a level of details that is sufficient for the purpose of the present study and it is based on the belt conveyor theory and calculation procedures proposed by Spivakovsky and Dyachkov in [13]. The values of various parameters included in design specifications are based on data extracted from relative technical literature $[2-5,13]$ and properly adapted in order to conform to the needs of the present study.

\section{Operative conditions}

The belt conveyor transports dry gravel of density dens $=1520 \mathrm{~kg} / \mathrm{m}^{3}$. The gravel is unloaded directly from the terminal pulley. It must convey in total $2500 \mathrm{t}$ for a time period of $5 \mathrm{~h}$ an for every working day. Due to other operational factors and constraints in the facility, it has been assumed that the conveyor will start at the beginning of its operation period and then it will continue runnig at constant speed equal to its rated one for $5 \mathrm{~h}$. It is also considered that feeding the conveyor with gravel follows conveyor start with a certain time delay 


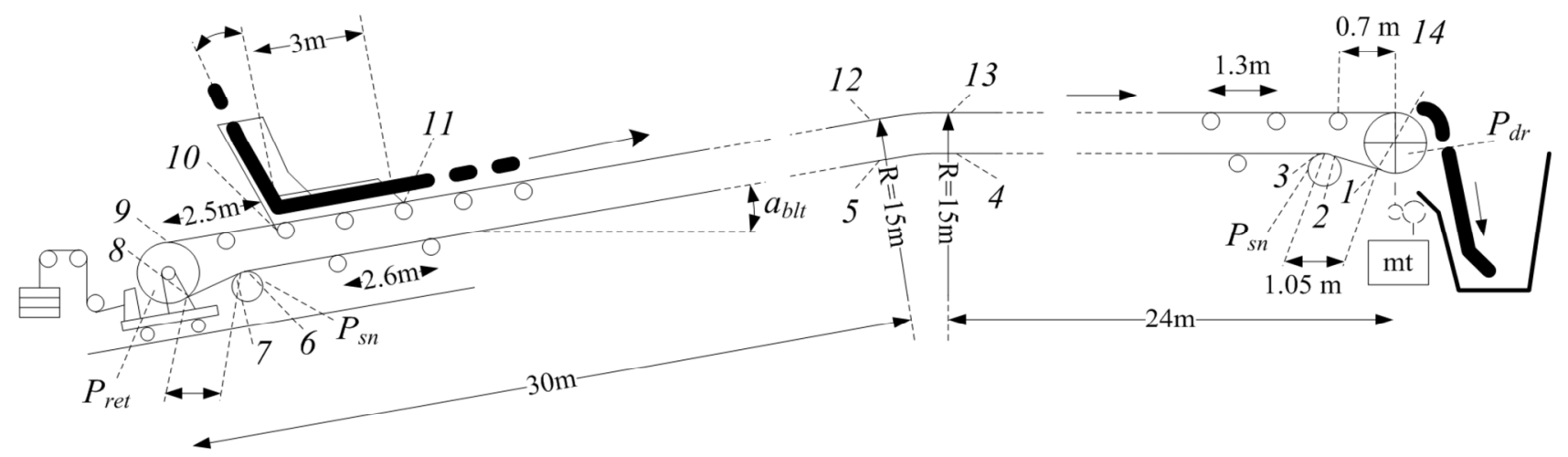

Figure 1. Abstract representation of the belt conveyor that is examined in case study

enough for the latter to reach its nominal steady-state operational speed. Finally, it is assumed that, for every work day, the operative and climate conditions (temperature, humidity etc.) remain the same.

\section{Design specifications}

The length $\left(L_{t r}\right)$ of the conveyor path is equal to $56.61 \mathrm{~m}$. The maximum rated capacity $\left(C_{r t}\right)$ is $650 \mathrm{t} / \mathrm{h}$, the rated speed $\left(v_{r t}\right)$ is $2.09 \mathrm{~m} / \mathrm{s}$ and the rated acceleration is $a c c=0.2 \mathrm{~m} / \mathrm{s}^{2}$. The belt is of 2-ply fabric carcass type having a width $w_{b l t}=1.2 \mathrm{~m}$ and linear mass $m_{b l t}=1.7 \mathrm{~kg} / \mathrm{m}$, while its section dimensions and its carcass structure may withstand the developed tension forces without failure. The minimum tension $\left(S_{\min }\right)$ applied to the belt by take-up device is $6000 \mathrm{~N}$.

The driving pulley $\left(\mathrm{Pl}_{\mathrm{dr}}\right.$ in figure 1$)$ has a diameter $d_{p l . d r}$ of $0.4 \mathrm{~m}$, mass $M_{p l . d r}$ equal to $80 \mathrm{~kg}$ and a moment of inertia $I_{p l . d r}$ that is equal to $3.2 \mathrm{kgm}^{2}$. The return pulley (abbr. $\mathrm{Pl}_{\text {ret }}$ in figure 1) has diameter $d_{\text {pl.ret }}=0.315$ $\mathrm{m}$, mass $M_{\text {pl.ret }}=63 \mathrm{~kg}$ and moment of inertia $I_{\text {pl.ret }}=$ $1.56 \mathrm{kgm}^{2}$. The two snub pulleys (abbr. $\mathrm{Pl}_{\mathrm{sn}}$ in figure 1) have diameter $d_{p l . s n}=0.25 \mathrm{~m}$, mass $M_{\text {pl.sn }}=50 \mathrm{~kg}$ and moment of inertia $I_{\text {pl.sn }}=0.78 \mathrm{kgm}^{2}$.

The support rollers in upper (carrying) and in lower (return) run of the conveyor have diameter $d_{s r l}=0.108 \mathrm{~m}$. In the carrying run, the support rollers have the form of 3part assemblies with troughing angle equal to $30^{\circ}$; there are $n u_{\text {carr.srl }}=47$ number of assemblies located every $l_{\text {carr.srl }}=1.2 \mathrm{~m}$, the mass of each assembly is $M_{\text {carr.srl }}=$ $16.3 \mathrm{~kg}$ and therefore their linear mass along the belt line is $m_{\text {carr.srl }}=27.16 \mathrm{~kg} / \mathrm{m}$. The moment of inertia of the upper support rollers is $I_{\text {carr.srl }}=0.048 \mathrm{kgm}^{2}$. In the return run, there are $n u_{\text {carr.srl }}=22$ number of assemblies with single support rollers mounted every $l_{\text {carr } / / s l}=2.6 \mathrm{~m}$, with each roller having a mass $M_{\text {ret.srl }}$ of $14.2 \mathrm{~kg}$, so that the linear mass $m_{\text {ret.srl }}=10.92 \mathrm{~kg} / \mathrm{m}$. The moment of inertia of lower support rollers is $I_{\text {ret.srl }}=0.041 \mathrm{kgm}^{2}$.

Focusing on coefficient of resistances to belt motion, $w_{\text {carr }}=0.029$ is the coefficient of resistance to the motion of the belt in the carrying run and $w_{\text {ret }}=0.022$ is the respective coefficient of resistance in the return run. The coefficient $\left(\zeta_{l}\right)$ of resistance to belt motion on the turning pulley is equal to 1.06 , while the respective coefficient $\left(\zeta_{2}\right)$ to the snub pulleys at points 2-3 and 6-7 of belt run is 1.02 given the small wrapping angles of the belt around them. Finally, the coefficient $\left(\lambda_{1}\right)$ of resistance to the belt motion on the curved roller set in carrying run equals to 1.05 and the respective coefficient of resistance to the belt motion on the curved roller set in the return run $\left(\lambda_{2}\right)$ is equal to 1.04.
The conveyor runs with an induction 3-phase motor that is coupled with a gear-box and it is supplied with electricity by a vvvf drive that keeps the starting current low. In the present study and for reasons of simplicity, a total efficiency coefficient of the whole drive mechanism $\left(n_{\text {dr.mech }}\right)$ is considered, being equal to 0.85 . The inertia of the whole driving mechanism, reduced to the outer power transmition shaft of the driving mechanism (the shaft that is coupled to the driving pulley) is given by its manufacturer and it is equal to $R I_{d r . m e c h}=2.5 \mathrm{kgm}^{2}$. The margin of adhesion $\left(K_{a d h}\right)$ between the belt and the driving pulley is assumed to be equal to 1.1.

Considering conveyor braking, even though there is a brake for the prevention of spontaneous reverse motion and for immediate stopping for reasons of safety, it is assumed that in normal conditions the conveyor decelerates under its resistances and only if all the load on the belt has prevously been unloaded.

The electrical sub-system includes lights, operation station with indicators and switches, safety circuits and the controller that includes the vvvf drive. The power used by the electrical sub-system is $P_{\text {elec }}=700 \mathrm{~W}$.

The loading station features a charging hopper and a guiding chute. The chute is supported on the belt with the use of tightening blades. The angle $\left(a_{h o p}\right)$ of material supply in relation to an axle that is vertical to the belt line is $25^{\circ}$. The speed $\left(v_{p r t}\right)$ of particles as supplied from the hopper is $2 \mathrm{~m} / \mathrm{s}$. The coefficient $\left(f_{\text {prt } / \text { side }}\right)$ of friction of material particles on side walls of the chute is for dry gravel 0.7 [13] (see expression 11). The calculated height $\left(h_{p r t / c h}\right)$ of the material layer at the chute wall is $0.3 \mathrm{~m}$. The length $\left(l_{c h}\right)$ of the chute walls is $3 \mathrm{~m}$. The coefficient $\left(\eta_{p / s i d e}\right)$ of pressure is estimated to be equal to 0.8 (the range reported in literature [13] is $0.6-0.9)$. Finally, the unit resistance $\left(K_{c h / b l t}\right)$ due to friction of the chute on the belt because of the tightening blades is $75 \mathrm{~N} / \mathrm{m}$ (see expression 12 ).

\section{$\underline{\text { Calculations }}$}

The linear mass (load) in $\mathrm{kg} / \mathrm{m}$ of the bulk load on the belt is given by the following expression (1), for various values of the actual mass capacity $(C)$ in $t / h$ and belt speed $(v)$ in $\mathrm{m} / \mathrm{s}$.

$$
m_{\text {load }}=C / 3.6 v
$$

When the capacity and speed reach their maximum rated values, then $l_{\text {oad }}=86.39 \mathrm{~kg} / \mathrm{m}$.

Considering belt tensions, the belt tension $\left(S_{l}\right)$ at point 1 (see figure 1), where the belt runs off the driving 
pulley, is proved to be the minimum one $\left(S_{\min }\right)$. The belt tension $\left(S_{2}\right)$ at point 2 can be considered as equal to tension $\left(S_{l}\right)$, as the belt does not move on return support rollers.

The belt tension $\left(S_{3}\right)$ at point 3 after the snub pulley that is located there for the increase of the wrapping angle of the belt on the driving pulley, derives from tension $\left(S_{2}\right)$, if the resistance to the belt turning motion on that pulley is calculated via the following simple expression $[4,13]$.

$$
S_{3}=\zeta_{2} S_{2}
$$

Next, the belt tension $\left(S_{4}\right)$ at point 4 of the conveyor layout is determined if, first, the resistance to the belt motion along the straight section 3-4 is estimated with the following expression $[2-4,13]$.

$$
S_{4}=S_{3}+w_{r e t} \cdot\left(m_{b l t}+m_{r e t . s r l}\right) \cdot g \cdot l_{3-4}
$$

Regarding the belt tension $\left(S_{5}\right)$ at point 5 after the curved section 4-5, a rather simple expression proposed in literature [13] that depicts the resistance of belts in curved sections is:

$$
S_{5}=\lambda_{2} \cdot S_{4}
$$

Then, the belt tension at point 6 after the linear part 5-6 of the return run of the conveyor is calculated by the following expression that incorporates additionally the affection of belt gravitational force $[2,4,13]$.

$$
\begin{aligned}
& S_{6}=S_{5}+w_{r e t} \cdot\left(m_{b l t}+m_{r e t . s r l}\right) \cdot g \cdot \cos \left(a_{b l t}\right) \cdot l_{5-6}- \\
& -m_{b l t} \cdot g \cdot \sin \left(a_{b l t}\right) \cdot l_{5-6}
\end{aligned}
$$

The tension $\left(S_{7}\right)$ at point 7 after the snub pulley on the left side of the return run is calculated in relation to $\left(S_{6}\right)$ as tension $\left(S_{3}\right)$ in relation to $\left(S_{2}\right)$, considering again the same coefficient $\left(\zeta_{2}\right)$. Then, similarly to the couple of tensions $\left(S_{1}\right)$ and $\left(S_{2}\right)$, it can be accepted that $S_{8}=S_{7}$.

The following part of the conveyer to be examined for its affection to the belt tension is the return pulley on the left side of the conveyor. It is:

$$
S_{9}=\zeta_{1} S_{8}
$$

Now, the resistances to belt motion in the upper carrying run of the conveyor must be taken into consideration, where the major difference from the calculation of the return run is the existence of the load. The analysis starts from the calculation of tension $\left(S_{10}\right)$ considering the resistances in the inclined linear part 910. It is:

$$
\begin{aligned}
& S_{10}=S_{9}+w_{c a r} \cdot\left(m_{b l t}+m_{c a r . s r l}\right) \cdot g \cdot \cos \left(a_{b l t}\right) \cdot l_{9-10}+ \\
& +m_{b l t} \cdot g \cdot \sin \left(a_{b l t}\right) \cdot l_{9-10}
\end{aligned}
$$

Next task before the calculation of tension $\left(S_{11}\right)$ is the estimation of the resistance $\left(W_{L S}\right)$ to belt motion in the loading station. Literature [13] provides with the following expression in case of loading stations that feature hopper and chute:

$$
W_{L S}=W_{a c}+W_{p r t / s i d e}+W_{\text {blade }}
$$

In this expression, first, $\left(W_{a c}\right)$ is the resistance due to the acceleration of the load when is fed on the belt:

$$
W_{a c}=0.1 \cdot m_{\text {load }} \cdot g \cdot\left(v^{2}-v_{p r t / b l t}^{2}\right)
$$

where, $\left(v_{\text {prt } / \text { blt }}^{2}\right)$ is the projection of the speed of particles as supplied from the charging hopper, therefore $v_{\text {prt } / b l t}=v_{p r t} \cdot \sin \left(a_{\text {hop }}\right)$ (see figure 1$)$.

Second, $\left(W_{\text {prt } t \text { side }}\right)$ is the resistance due to friction of material particles on stationary sides of the guide chute:

$$
W_{p r t / s i d e}=f_{p r t / s i d e} \cdot h_{p r t / c h} \cdot \rho \cdot g \cdot l_{c h} \cdot \eta_{p / s i d e}
$$

Third, $\left(W_{\text {blade }}\right)$ is the resistance due to friction of tightening blades of the loading chute on the belt.

$$
W_{c h / b l t}=K_{c h / b l t} \cdot l_{c h}
$$

The tension $\left(S_{11}\right)$ is calculated if between points 10 and 11 of the belt line, the resistances from the loading station and to the belt motion on the support rollers are considered accumulatively.

$$
\begin{aligned}
& S_{11}=S_{10}+W_{L S}+ \\
& +w_{\text {carr }} \cdot\left(m_{\text {load }}+m_{\text {blt }}+m_{\text {carr.srl }}\right) \cdot g \cdot \cos \left(a_{b l t}\right) \cdot l_{c h}+ \\
& +\left(m_{\text {load }}+m_{\text {blt }}\right) \cdot g \cdot \sin \left(a_{b l t}\right) \cdot l_{c h}
\end{aligned}
$$

The tension $\left(S_{12}\right)$ occurs after the calculation of the resistance to belt motion in inclined linear part between points 11-12.

$$
\begin{aligned}
& S_{12}=S_{11}+ \\
& +w_{\text {carr }} \cdot\left(m_{\text {load }}+m_{\text {blt }}+m_{\text {carr.srl }}\right) \cdot g \cdot \cos \left(a_{b l t}\right) \cdot l_{9-10}+ \\
& -\left(m_{\text {load }}+m_{\text {blt }}\right) \cdot g \cdot \sin \left(a_{\text {blt }}\right) \cdot l_{9-10}
\end{aligned}
$$

Next, the increase of belt tension in curved roller set in part $12-13$ of the carrying run is depicted via the following expression:

$$
S_{13}=\lambda_{1} \cdot S_{12}
$$

Finally, the tension $\left(S_{14}\right)$ to the belt line point 14 where the belt runs on the driving pulley derives from tension $\left(S_{13}\right)$ if, the resistances in the linear part 13-14 of the horizontal carrying run of the conveyor are calculated.

$$
\begin{aligned}
& S_{14}=S_{13}+ \\
& +w_{\text {carr }} \cdot\left(m_{\text {load }}+m_{\text {blt }}+m_{\text {carr.srl }}\right) \cdot g \cdot l_{13-14}
\end{aligned}
$$

The tension $\left(S_{o n}\right)$ of the part of the belt that goes on the driving pulley is apparently $S_{o n}=S_{14}$, while the tension $\left(S_{\text {off }}\right)$ of the part of the belt that goes of the driving pulley is $S_{\text {off }}=S_{l}$. The circumferential tractive force $\left(W_{p l}\right)$ transmitted by the driving pulley to the belt is:

$$
W_{p l . d r}=S_{o n}-S_{o f f}
$$

Considering now the margin of adhesion $\left(K_{a d h}\right)$, the required power of the drive motor is determined by the formula:

$$
N=K_{a d h} \cdot W_{p l . d r} \cdot v / n_{d r . m e c h}
$$

The energy consumed during a period with index $(T P)$ in steady-state conveyor operation is: 


$$
E_{\text {steady.st }}=N \cdot t_{T P}
$$

To continue, for the estimation of the total energy consumption during the operation of the conveyor, the energy consumed during its acceleration every time it starts to run should be calculated. It consists of the energy needed to overcome the resistances to belt motion and the energy needed for the acceleration of masses of belt, pulleys, support rollers and rotating parts of the drive mechanism.

To calculate energy consumption during conveyor starting, first tensions $\left(S_{14}\right)$ and $\left(S_{1}\right)$ should obtain their values by expressions (3) to (16) considering that the conveyor is not charged with gravel by the loading station, as it is assumed that the conveyor starts always empty. That means that in tension calculation expressions the parameter (load) is omitted and that $\left(W_{L S}\right)$ in expression (9) equals only to $\left(W_{\text {blade }}\right)$. Then, the tractive force $\left(W_{\text {pl.dr/empty }}\right)$ that is transmitted by the driving pulley to the belt and that corresponds to resistances to the belt motion without any load, is calculated by expression (17).

Next, the tractive force $\left(W_{\text {pl.dr/acc }}\right)$ transmitted by the driving pulley that is responsible for the acceleration of conveyor moving masses except of the driving pulley per se, is given by the next formula.

$$
\begin{aligned}
& W_{p l . d r / a c c}=a c c \cdot\left[m_{b l t} \cdot l_{b l t}+\frac{I_{p l . r e t}}{\left(d_{p l . r e t} / 2\right)^{2}}+\right. \\
& +2 \frac{I_{p l . s n}}{\left(d_{p l . s n} / 2\right)^{2}}+n u_{\text {carr } / s r l} \cdot \frac{I_{\text {carr.srl }}}{\left(d_{\text {carr.srl }} / 2\right)^{2}}+ \\
& \left.+n u_{\text {ret } / \text { srl }} \cdot \frac{I_{\text {ret.srl }}}{\left(d_{\text {ret.s.sl }} / 2\right)^{2}}\right]
\end{aligned}
$$

Here, $\left(l_{b l t}\right)$ is the total length of the belt including the lengths of the belt around the driving and return pulley.

The total tractive force $\left(W_{\text {pl.dr/start }}\right)$ transmitted by the driving pulley in each conveyor start is:

$$
W_{p l . d r / s t a r t}=W_{p l . d r / e m p t y}+W_{p l . d r / a c c}
$$

Then the respective applied torque $\left(M_{\text {pl.dr/shaftstart }}\right)$ on the shaft of the driving pulley is:

$$
\begin{aligned}
& M_{p l . d r / \text { shaft } / \text { start }}=K_{a d h} \cdot W_{p l . d r / s t a r t} \cdot \frac{d_{p l . d r}}{2}+ \\
& +a c c \cdot \frac{I_{p l . d r}}{\left(d_{p l . d r} / 2\right)^{2}}
\end{aligned}
$$

Considering now the moment of inertia $\left(F I_{d r . m e c h}\right)$ of rotating masses in driving mechanism that is reduced to power transmitting shaft that is coupled to driving pulley, it can be proposed that the total consumed energy $\left(E_{\text {start }}\right)$ during each starting process of the conveyor is calculated via the next expression.

$$
\begin{aligned}
& E_{\text {start }}=\left(M_{p l . d r / s h a f t / s t a r t} \cdot \int_{0}^{v / a c c} \frac{a c c}{d_{p l . d r} / 2} \cdot t d t+\right. \\
& \left.+F I_{d r . \text { mech }} \cdot \frac{a c c}{d_{p l . d r} / 2} \cdot \int_{0}^{v / a c c} \frac{a c c}{d_{p l . d r} / 2} \cdot t d t\right) / n_{d r . \text { mech }}
\end{aligned}
$$

During a sub-period $(T P)$, the parameter $\left(E_{T P}\right)$ of (ISEP) in expression (1) equals to the following sum.

$$
E_{T P}=E_{\text {steady.st } / T P}+n a c_{T P} \cdot E_{\text {start }}+P_{\text {elec }} \cdot t_{T P}
$$

Here, $\left(n a c_{T P}\right)$ is the number of conveyor starts during sub-period $(T P)$.

The parameter $\left(t_{t r / T P}\right)$ equals to $L_{t r} / v$, and in case of variable speed values during a period $(T P)$, it can take average values.

For the operative conditions given in the description of the problem, a working day can be represented by a single $(T P)$ and the daily steady state energy $E_{\text {steady } / \text { st } / D}=$ $320540 \mathrm{~kJ}$, the daily consumed energy for all starts $E_{\text {start } / D}=28.81 \mathrm{~kJ}$, the daily total consumed energy $E_{D}=$ $333170 \mathrm{~kJ}$ and the daily $I S E P_{D}=63.77 \mathrm{~J} \cdot \mathrm{s} / \mathrm{kg} \cdot \mathrm{m}$.

Alternative scenario 1: Design of a belt conveyor with some components of higher efficiency

The changes in the alternative design are: The belt is of 1-ply fabric carcass type with linear mass $m_{b l t}=1.43$ $\mathrm{kg} / \mathrm{m}$. The pulleys are smaller; driving pulley: $d_{p l . d r}=$ $0.315 \mathrm{~m}, M_{p l . d r}=63 \mathrm{~kg} I_{p l . d r}=1.56 \mathrm{kgm}^{2}$; return pulley: $d_{\text {pl.ret }}=0.25 \mathrm{~m}$, mass $M_{\text {pl.ret }}=50 \mathrm{~kg}$ and moment of inertia $I_{\text {pl.ret }}=0.78 \mathrm{kgm}^{2}$; snub pulleys: $d_{p l . s n}=0.20 \mathrm{~m}$, mass $M_{p l . s n}=40 \mathrm{~kg}$ and moment of inertia $I_{p l . s n}=0.4$ $\mathrm{kgm}^{2}$. Carrying support rollers with $M_{\text {carr.srl }}=15.0 \mathrm{~kg}$ and $I_{\text {carr.srl }}=0.044 \mathrm{kgm}^{2}$. Resistance coefficients: in the carrying run $w_{\text {carr }}=0.0275$, on the turning pulley $\zeta_{I}=$ 1.04. Drive mechanism coefficient $n_{\text {dr.mech }}=0.9$; power used by the electrical sub-system: $P_{\text {elec }}=620 \mathrm{~W}$. Angle of material supply: $a_{\text {hop }}=30^{\circ}$.

For the same operative conditions, the daily steady state energy $E_{\text {steady/st/D }}=293940 \mathrm{~kJ}$, the daily consumed energy for all starts $E_{\text {start } / D}=26.60 \mathrm{~kJ}$, the daily total consumed energy $E_{D}=305130 \mathrm{~kJ}$ and the daily $I S E P_{D}=$ $58.40 \mathrm{~J} \cdot \mathrm{s} / \mathrm{kg} \cdot \mathrm{m}$.

It is more than clear that it is a way more efficient machine and (ISEP) follows efficiently the increase of energy performance.

Alternative scenario 2: The conveyor is installed and operative conditions get improved

Managers of the facility managed to regulate the other operations so that the conveyor should operate 4 times for $1 \mathrm{~h}$ each, thus, the times of conveyer acceleration $n a c=4$. The requested $C=625 \mathrm{t} / \mathrm{h}$ is much closer to the rated handling capacity of the conveyor. The angle of material supply becomes $a_{\text {hop }}=35^{\circ}$. The conveyor is cleaned often and the resistance coefficients become in the carrying run $w_{\text {carr }}=0.0285$; on the turning pulley $\zeta_{1}=1.046$.

The minimum belt tension $\left(S_{\min }\right)$ is reconfigured regarding the allowable sag of the belt between roller supports. For the linear part of the upper carrying run of the belt in case of bulk load conveying, Spivakovsky and Dyachkov [13] propose the next expression.

$$
S_{\text {min }} \geq K_{\text {sag }} \cdot\left(m_{\text {load }}+m_{\text {blt }}\right) \cdot g \cdot l_{\text {carr.srl }}
$$

Here, $\left(K_{\text {sag }}\right)$ is the coefficient of belt sag with value equal 5 , given that the total length is shorter than $100 \mathrm{~m}$ and that the path is relatively simple [13]. The new $S_{\min }$ $=4974 \mathrm{~N}$, significantly lower than the initial one. 
In this case the daily steady state energy $E_{\text {steady } / \text { st } / D}=$ $287300 \mathrm{~kJ}$, the daily consumed energy for all starts $E_{\text {start } / D}=103.58 \mathrm{~kJ}$, the daily total consumed energy $E_{D}$ $=297490 \mathrm{~kJ}$ and the daily $I S E P_{D}=56.94 \mathrm{~J} \cdot \mathrm{s} / \mathrm{kg} \cdot \mathrm{m}$.

The energy consumption results show powerfully the improvement in energy efficiency, however, the $\left(I C E D_{D}\right)$ follows additionally the improvement of transportation service and it obtains a significantly lower value than that in initial conditions of the problem, even though the changes in hardware are modest.

It is obvious a further redesign of belt conveyor along with a further optimization of operative conditions could lead to an interestingly even lower (ISEP).

\section{CONCLUSION}

In the present paper, an Index of Service-Energy Performance (ISEP) for belt conveyors is proposed. It is an index for the evaluation of the overall efficiency of a conveyor considering both energy and service performance. It depicts the energy consumed by a conveyor in relation to the amount of conveyed material, the covered distance and the time needed for the transportation of a material unit mass.

The index can be used for the evaluation regarding the overall efficiency of: a. candidate design solutions when the conveyor is under development or is modernized, b. operational decisions, $\mathrm{c}$. the maintenance efficiency if the data that affect the calculation of (ISEP) come from measurements on the field and $d$. if the handling capacity requirements vary but the energy efficiency of the conveyor should remain at the same levels or improved.

In the present study, (ISEP) is exemplified with the use of simple inclined belt conveyor as a paradigm. The energy data that feed the index are derived from a detailed, yet simple, energy calculation model that has been tailored for the specific conveyor and considers the steady state operation and the acceleration phase. The model takes also into account the conveying requirements and the operational decisions by the facility managers.

The case study proved that (ISEP) represents efficiently and adapts to the variations in technical specifications and operational conditions of the examined belt conveyors.

Future work could involve the development of more detailed energy analysis models for belt conveyors as well as the application of (ISEP) to other conveyor types. (ISEP) could be also used for the characterization of a whole infrastructure of conveyors, i.e. how efficient is the relation between transportation service and energy consumption considering the transportation of a certain load of materials between two points within the limits of a production facility.

\section{REFERENCES}

[1] Clenet, D.: Optimizing energy efficiency of conveyors, White paper WP20100601EN, Schneider Electric S.A., 2010

[2] Continental: CONTI Conveyor Belt Service Manual, Conveyor Belt System Design, Revised edition 1988, Continental Aktiengesellschaft, Hannover 1988
[3] Conveyor Equipment Manufacturers Association Engineering Conference: Belt Conveyors for Bulk Materials $5^{\text {th }}$ Edition, The Conveyor Equipment Manufacturers Association, 1997

[4] Dentsoras, A.: Material Conveying Machines, University of Patras, Patras, 2009 (in Greek)

[5] Fayed, M., Skocir, T.: Mechanical Conveyors, Selection and Operation, Technomic Publishing Company Inc, Lancaster, 1997

[6] Gunthner, W., Tilke, Ch., Rakitcsch, G.: Energy efficiency in bulk materials handling, Bulk Solids Handling, vol. 30, pp. 138-142, 2010

[7] Hager, M., Hintz, A.: The energy saving design of belts for long conveyor systems, Bulk Solids Handling, Vol.13, No.4, pp.749-758, 1993

[8] He, D., Pang, Y., Lodewijks, G.: Green operations of belt conveyors by means of speed control, Applied Energy, vol. 188, pp. 330-341, 2015

[9] Luo, J., Huang, W., Zhang, S.: Energy cost optimal operation of belt conveyors using model predictive control methodology, Journal of Cleaner Production, vol. 105, pp. 196-205, 2015

[10] Markos, P., Dentsoras, A.: Energy representation via design function structure for multi-attribute optimization of traction elevator systems. International Design Conference "Design 2014", Dubrovnik, Croatia, May 2014.

[11] Markos, P., Dentsoras A.: Energy consumption and service performance of escalators. FME Transactions (2016) 44, pp. 249-255.

[12] Mathaba, T., Xia, X.: A parametric energy model for energy management of long belt conveyors, Energies, vol. 8, pp. 13590 - 13608, 2015

[13] Spinakovsky, A., Dyachov, V.: Conveying Machines, Mir Publishers, Moscow, 1985

[14] Wheeler, C.: Rotating resistance of belt conveyor idler rolls, Journal of Manufacturing Science and Engineering, vol. 138, pp. 041009-1 to 041009-8, 2016

[15]Zhang, S., Xia, X.: Modeling and energy efficiency optimization of belt conveyors, Applied Energy, vol. 88 , pp. 3061-3071, 2011

\section{ИНДЕКС КОЈИ ПОВЕЗУЈЕ РАДНИ УЧИНАК И ПОТРОШЫУ ЕНЕРГИЈЕ КОД ТРАКАСТИХ КОНВЕЈЕРА}

\section{П. Маркос, А. Дентсорас}

Предложен је индекс процене ефикасности укупне функционалности/дизајна тракастих конвејера, који узима у обзир енергетски и радни учинак. Вредност индекса се добија тако што се подаци о потрошњи енергије, добијени подробном анализом потрошње енергије конвејера, повезују са подацима о радном учинку, добијеним анализом капацитета транспорта материјала, у контексту одређених радних захтева и услова функционисања. Пример предложеног индекса приказан је у студији случаја једноставног тракастог 
косог конвејера за који је развијен модел потрошње енергије у појединостима. Испитане су различите техничке спецификације и радни услови. Предложени приступ доказује да индекс адекватно приказује утицај сваког пројектног решења или одлуке о раду конвејера на његову укупну искоришћеност. 